\title{
Penafsiran Tekstual Terhadap Ayat-Ayat Gender: Telaah Penafsiran Wahbah az-Zuhaili Dalam Kitab Tafsir al-Munir
}

\author{
Eko Zulfikar ${ }^{1}$, Ahmad Zainal Abidin ${ }^{2}$ \\ IAIN Tulungagung, Indonesia \\ 11ekozulfikar2020@gmail.com,2ahmadzaina17474@gmail.com
}

DOI: http://dx.doi.org/10.29240/alquds.v3i2.829

Submitted: 2019-04-22 | Revised: 2019-10-18|Accepted: 2019-10-23

\begin{abstract}
This paper discusses several interpretations of the verse about gender in the Tafsir al-Munir by Wahbah az-Zuhaili.The themes discussed include; the origin of women's creation, the 1:2 inheritance formula for women, and women's leadership in the household. Using the method of constructivism and analysis of intertextuality data, this paper concludes that the interpretation put forward by az-Zuhaili related to these three themes has a different understanding from the contemporary commentators. In the first interpretation (the origin of the creation of women), az-Zuhaili seems to carry gender equality. While the other two things (the inheritance formula 1:2 and household leadership), the interpretation seems to contain subordination (women are lower than men) and marginalization (impoverishment) for women. These three interpretive themes about gender verses show that az-Zuhaili interpreted them in a textual way not contextual. Though he lives in contemporary times which incidentally the majority of commentators interpret the Qur'anic verses in a contextual way.
\end{abstract}

Keywords: gender, textual-contextual, interpretation of the Qur'an, Wahbah az-Zuhaili

\begin{abstract}
Abstrak: Tulisan ini mendiskusikan beberapa penafsiran ayat tentang gender dalam Tafsir al-Munir karya Wahbah az-Zuhaili. Adapun tema yang dibahas antara lain; asal mula penciptaan perempuan, formula waris 1:2 bagi perempuan, dan kepemimpinan perempuan dalam rumah tangga. Dengan menggunakan metode konstruktivisme dan analisa data intertekstualitas, tulisan ini memberi kesimpulan bahwa penafsiran yang dikemukakan az-Zuhaili terkait tiga tema tersebut memiliki pemahaman berbeda dengan mufasir sezamannya. Dalam penafsiran pertama (asal mula penciptaan perempuan), az-Zuhaili tampaknya membawa kesetaraan gender. Sementara dua hal lainnya (formula pewarisan 1:2 dan kepemimpinan rumah tangga), penafsirannya tampak mengandung subordinasi (perempuan lebih rendah daripada laki-laki) dan marginalisasi (pemiskinan) bagi perempuan. Tiga tema penafsiran tentang ayat gender ini menunjukkan, bahwa az-Zuhaili menafsirkannya dengan cara tekstual - tidak kontekstual. Padahal ia hidup pada zaman kontemporer yang notabene mayoritas mufasir menafsirkan ayat Alquran dengan cara kontekstual.
\end{abstract}


Kata kunci: gender, tekstual-kontekstual, tafsir Alquran, Wahbah az-Zuhaili

\section{Pendahuluan}

Secara faktual, tidak sedikit para mufasir yang melakukan upaya memahami ayat Alquran dengan cara tekstual ataupun kontekstual. Hasil dari pendekatan dengan menafsirkan secara tekstual-kontekstual ini dianggap telah melahirkan makna berbeda tentang problema gender. Dewasa ini, para mufasir kontemporer mencoba menganalisa ayat gender dengan pendekatan kontekstual dalam penafsirannya, dan penafsiran mereka dinilai tidak bias gender dan berhasil adil gender. Namun demikian, terdapat pula penafsiran yang menghasilkan sebuah makna, di mana budaya patriarki menghegemoni kesadaran dalam memahami ayat-ayat tentang gender. ${ }^{1}$ Hal ini sejatinya karena dipengaruhi kondisi sosial politik budaya yang ada yang mengiringi kehidupan sang mufasir, karena hasil penafsiran tidak hanya lahir dari pendekatan dan metode, namun juga lahir dari kondisi sosial politik budaya dan ideologi mereka.

Wahbah az-Zuhaili adalah satu di antara sosok para mufasir yang telah ikut berpartisipasi dalam meramaikan wacana tafsir gender pada periode kontemporer di dunia Islam. Buah pemikirannya terkait ayat-ayat gender telah ia tuangkan melalui karya monumentalnya kitab Tafsir al-Munir. Kendati tafsir ini populer dengan pembahasan nalar fiqihnya, namun tidak dapat dipungkiri posisi az-Zuhaili dalam mata rantai perkembangan tafsir gender tampaknya layak diperhatikan. Selain alasan karena az-Zuhaili hidup pada periode kontemporer yang notabene mayoritas para mufasir menafsirkan Alquran secara kontekstual, juga sejauh penelusuran penulis, az-Zuhaili tampak cenderung menafsirkan ayatayat gender secara tekstual, suatu kecenderungan yang sangat dominan di masa lalu.

Problema inilah yang kemudian melatarbelakangi penulis untuk meneliti lebih jauh karya tafsir az-Zuhaili yang bernuansa fiqhi, yaitu Tafsir al-Munir tentang ayat-ayat gender. Bagaimana di dalam karyanya, az-Zuhaili berusaha menampilkan penafsiran berbeda pada ayat-ayat gender dengan penjelasan tafsir yang serumpun dengannya. Bagaimana ia menggunakan beberapa riwayat yang ia kutip untuk mendukung pandangannya. Penelitian ini berusaha mengungkap bagaimana pandangan Wahbah az-Zuhaili tentang ayat-ayat yang berbicara kesetaraan gender dalam kitab Tafsir al-Munir.

Untuk mendapatkan pemahaman yang komprehensif, penulis mencoba membacanya dengan metode konstruktivisme, yakni landasan berfikir filosofis

\footnotetext{
${ }^{1}$ Patriarki adalah struktur kekuasaan atau hegemoni kekuatan dunia laki-laki, di mana setiap hubungan dipahami dalam kerangka superioritas dan inferioritas. Lihat, Mansour Fakih, "Posisi Perempuan dalam Islam; Tinjauan dari Analisis Gender", dalam Membincang Feminisme, Diskursus Gender Perspektif Islam, (Surabaya: Risalah Gusti, 1996), 215.
} 
dalam membangun tata susunan pengetahuan yang dilakukan secara perlahan. Selain itu, penulis melakukan studi kepustakaan (library research) yang menitikberatkan pada Tafsir al-Munir sebagai sumber utama tanpa mengenyampingkan data lain sebagai data sekunder. Penelitian ini juga bersifat kualitatif-deskriptif dengan menggunakan teknik analisis, yaitu menganalisa data dengan cara intertekstualitas, yaitu proses dalam memahami sebuah teks untuk memperoleh makna yang merubah rupa dari teks sebelumnya. Namun sebelum ke poin tersebut, perlu dikemukakan gambaran ringkas tentang pengarang dan tafsir yang menjadi konsen tulisan ini.

\section{Biografi Singkat Wahbah az-Zuhaili}

Penulis produktif ini bernama lengkap Wahbah bin Mushthafa bin Wahbah az-Zuhaili, putra dari Syaikh Mushthafa az-Zuhaili, seorang petani sederhana nan alim, hafal Alquran, rajin beribadah dan gemar berpuasa dari negeri Syiria. Wahbah az-Zuhaili lahir pada 6 Maret $1932 \mathrm{M} / 1351 \mathrm{H}$ bertempat di Dair 'At jiyyah Faiha, Provinsi Damaskus. ${ }^{2}$ Setelah memberikan darma baktinya kepada umat dan masyarakat Muslim, az-Zuhaili menghembuskan nafas terakhirnya pada malam Sabtu 8 Agustus 2015 pada usia 83 tahun. ${ }^{3}$

Pendidikan az-Zuhaili dimulai pada saat kecil dibawah tuntunan orang tuanya dengan belajar ilmu-ilmu dasar agama Islam. Kemudian ia berlanjut sekolah dasar di daerahnya hingga tahap perguruan tinggi. ${ }^{4}$ Afiliasinya di Fakultas Syariah Universitas Damaskus, az-Zuhaili mendapat gelar sarjana pada tahun 1952 M, sementara gelar sarjana pada Pendidikan Islam ia raih di Universitas al-Azhar pada tahun 1956 M. Setelah itu, az-Zuhaili berhasil menamatkan program magister bidang Syariah di Universitas al-Azhar pada tahun 1959 M, dan meraih gelar doktoral pada tahun 1963 M di bidang dan Universitas yang sama. ${ }^{5}$

Setelah selesai mengenyam pendidikan intelektual akademik, az-Zuhaili berkiprah sebagai dosen pada tahun 1963 M di Fakultas Syariah Universitas Damaskus selaku almamaternya. Karir akademiknya terus melambung sampai ia mendapat jabatan sebagai wakil dekan pada Fakultas yang sama. Dengan waktu yang relatif singkat, az-Zuhaili dapat menggengam jabatan dekan sekaligus ketua

2 Saiful Amin Ghafur, Mozaik Mufasir al-Qur'an dari Klasik Hingga Kontemporer, (Yogyakarta: Kaukaba, 2013), 136.

3 http://www.hidayatullah.com/berita/internasional/read/2015/08/09/75463/ulamakontemporer-dunia-syeikh-wahbah-zuhaili-berpulang.html. Diakses selasa, 12 November 2018.

${ }^{4}$ Muhammad 'Ali Iyazi, al-Mufassirun Hayatubum wa Manhajubum, (Teheran: Muassasah at-Thiba'ah wa al-Irsyad al-Islami, 1993), 684.

${ }^{5}$ Saiful Amin Ghafur, Mozaik, Mufasir al-Qur'an., 137. 
jurusan Fiqh al-Islami setelah masa pengangkatanya sebagai wakil dekan. Tidak lama kemudian, ia dilantik sebagai guru besar dalam disiplin ilmu hukum Islam pada salah satu Universitas di Syiria. Az-Zuhaili merupakan tokoh masyhur abad ke $20 \mathrm{M}$ yang sejajar dengan tokoh-tokoh fenomenal dalam bidang fiqih, tafsir, dan berbagai disiplin ilmu ke-Islaman lainnya, seperti Muhammad Abu Zahrah, Sa'id Hawwa, Sayyid Quthb, Mahmud Syalthuth, Thahir Ibn 'Asyur, dan lainlain. $^{6}$

Meskipun az-Zuhaili hidup dalam ruang lingkup para ulama madzhab Hanafi yang secara langsung mempengaruhi pemikirannya dalam madzhab fiqih, namun ia meninggalkan fanatisme jauh-jauh dari madzhabnya serta menghargai keragaman perbedaan pendapat dengan bersikap netral, moderat dan proporsional terhadap pendapat madzhab lain. Hal ini tertuang dalam penafsirannya ketika ia membahas ayat-ayat yang berkaitan dengan fiqih. ${ }^{7}$ Dalam perkembangannya, Ia dikenal memiliki independensi dan obyektifitas yang tinggi berkaitan dengan perbedaan pendapat yang ada, sehingga ia familiar disebut sebagai oknum perbandingan madzhab (muqaranat al-madzabib) dengan salah satu bukti karya monumentlanya al-Figh al-Islami wa Adillatubu.

Sebagai seorang ulama yang lahir dari zamannya, tidak dapat dipungkiri bahwa guru dan murid memberikan warna yang niscaya dan tidak dapat dipisahkan. Dalam bidang fiqih, guru-guru az-Zuhaili antara lain; Muhammad Hasyim al-Khathib as-Syafi'i, dan 'Abd ar-Razzaq al-Hamasi. Dalam bidang ilmu hadis, az-Zuhaili pertama kali belajar dari Mahmud Yassin, dan dalam bidang ilmu tafsir ia berguru dengan Syaikh Hasan Jankah dan Syaikh Shadiq Jankah alMadani. Ilmu bahasa Arab dipelajarinya dari Muhammad Shalih Farfur. Sedangkan ketika di Mesir, ia berguru kepada Mahmud Syalthuth, 'Abd arRahman Taj, dan 'Isa Manun yang merupakan gurunya di bidang ilmu fiqih Muqaran (perbandingan). Adapaun gurunya dalam bidang ushul fiqih adalah Musthafa 'Abd al-Khaliq dan anaknya 'Abd al-Ghani, serta masih banyak lagi guru-guru yang lainnya. ${ }^{8}$

Wahbah az-Zuhaili merupakan seseorang yang menempati posisi sentral di kalangan ahli ilmu khususnya dibidang fiqih dan tafsir. Ia aktif menjalankan edukasinya melalui perkuliahan, diskusi, dakwah, dan juga ceramah melalui media massa. Ia tercatat mempunyai beberapa buah karya, antara lain; al-Fiqh alIslam wa Adillatubu, Usbul al-Figh al-Islam al-Wasith fi Ushul al-Figh, al-Fiqh al-Islam fi Uslub al-Jadid, Fiqh al-Mawaris fi as-Syari'at al-Islamiyyah, Alquran al-Karim; Bunyatubu at-Tasyri'iyyah an Khasha'ishubu al-Hasariyah, al-Asas wa al-Mashadir al-

6 Baihaki, "Studi Kitab Tafsir al-Munir Karya Wahbah az-Zuhaili dan Contoh Penafsirannya tentang Pernikahan Beda Agama,” ANALISIS 16, No. 1, (2016), 129.

7 'Ali 'Tyazi, al-Mufasirun Hayatubum wa Manahajubum., 684.

${ }^{8}$ Baihaki, "Studi Kitab Tafsir al-Munir., 130. 
Ijtibad al-Musytarikah Baina as-Sunnah wa as-Syi'ah, Abkam al-Harb fi al-Islam wa Khasha'ishuba al-Insaniyyah, Akblaq al-Muslim: al-Muwazanah baina al-Kitab wa asSunnah fi al-Abkam, al-Usrah al-Muslimah fi al-'Alam al-Mu'ashir, al-Islam wa Usbul al-Hadharah al-Insaniyyah, Ushul al-Iman wa al-Islam, Haqq al-Hurriyyah fi al-'Alam, dan al-'Alaqat ad-Dauliyyah fi al-Islam Muqaranah bi al-Qanun ad-Dauli al-Hadits."

Di dalam bidang tafsir secara khusus, Wahbah az-Zuhaili memiliki tiga karya monumental yang didedikasikan bagi kalangan berbeda. Hal ini karena perbedaan motivasi intrinsik dan faktor eksternal antara lain berupa kesempatan dalam membaca dan mengkaji. Ketiga karya tafsir ini masing-masing juga memiliki ciri dan karakterestik tersendiri. Deskripsi singkat dari ketiga tafsir tersebut adalah sebagai berikut:

1. Tafsir al-Munir fi al-'Aqidah wa as-Syari'ab wa al-Manbaj, diterbitkan dalam 16 volume yang diperuntukkan bagi para pengkaji yang memiliki keseriusan mendalam (ahl al-ikhtishash), seperti para akademisi dan ulama. ${ }^{10}$

2. Tafsir al-Wajiz, diperuntukkan bagi kalangan awam dan mayoritas pembaca pada umumnya (al-'ammah wa aktsariyyah an-nas). ${ }^{11}$

3. Tafsir al-Wasith, diperuntukkan bagi para pengkaji yang memiliki wawasan pengetahuan setingkat akademisi (mutawasith at-tsaqafah), diterbitkan dalam 3 volume yang berisi indeks ensiklopedis dan tematis darinya. ${ }^{12}$

Distingsi mendasar ketiga tafsir tersebut adalah bahwa Tafsir al-Wajiz. secara umum hanya menjelaskan sebagian dari ayat Alquran dan tidak dikupas secara panjang lebar. Cakupan penjelasannya ditulis oleh az-Zuhaili dalam bentuk catatan pinggir sembari mencantumkan asbab al-nu₹ul ayatnya. Tujuan tafsir ini tidak lain hanyalah untuk memudahkan masyarakat awam dalam memahami kandungan makna di dalamnya. Sementara Tafsir al-Wasith merupakan hasil persentasi az-Zuhaili selama tujuh tahun, mulai dari tahun 1992 sampai tahun 1998 M. Dalam hal ini, az-Zuhaili selalu mempresentasikan buah pemikirannya lewat media masa Syiria dengan durasi waktu 6-10 menit setiap harinya - kecuali hari libur. Kemudian hasil dari kompilasi seluruh persentasinya ini dibukukan menjadi sebuah kitab tafsir Alquran utuh sampai tiga puluh juz, terdiri dari tiga jilid dan dicetak pada tahun $1421 \mathrm{H}^{13}$ Sedangkan nama Tafsir al-

\footnotetext{
${ }^{9}$ Saiful Amin Ghafur, Mozaik. Mufasir al-Qur'an., 137.

10 Wahbah az-Zuhaili, al-Tafsir al-Munir fi al-'Aqidah wa as-Syari'ah wa al-Manbaj, Juz I, (Damaskus: Dar al-Fikr, 2006), 8.

${ }^{11}$ Wahbah az-Zuhaili, al-Tafsir al-Wajiz 'ala Hamisy al-Qur'an al-'Azhim (Damaskus: Dar al-Fikr, 1994), 1.

12 Wahbah az-Zuhaili, al-Tafsir al-Wasith, Juz I, (Damaskus: Dar al-Fikr, 2006), 5-6.

${ }^{13}$ Lihat dalam muqaddimah, Wahbah az-Zuhaili, al-Tafsir al-Wasith, 6.
} 
Munir merupakan karya popular dan monumental az-Zuhaili dalam bidang tafsir, yang akan dibahas pada poin berikut ini.

\section{Kitab Tafsir al-Munir: Sebuah Kajian Teoretis}

Kitab tafsir ini ditulis oleh Wahbah az-Zuhaili kurang lebih selama 16 tahun, mulai dari tahun 1975 sampai tahun 1991 M. Kitab tafsir ini menerangkan seluruh ayat Alquran secara ekstensif mulai dari surah al-Fatihah sampai dengan surah al-Nas, terdiri dari 16 jilid dan masing-masing jilid memuat 2 juz, sehingga secara keseluruhan berjumlah 32 juz. Untuk dua juz terakhir, azZuhaili menengarai dengan nama al-fahras al-syamil, berisikan indeks yang disusun secara alfabetis.

Dalam dunia akademik, az-Zuhaili telah menjalankan misi edukatif di perguruan tinggi selama kurang lebih 30 tahun dan melakukan banyak riset dalam berbagai disiplin ilmu, termasuk fiqih, tafsir dan hadis. Bersamaan dengan itu pula, az-Zuhaili mengarang kitab Tafsir al-Munir setelah menamatkan penulisan dua kitab monumentalnya yang komprehensif, yaitu Ushul Fiqh al-Islam dan al-Figh al-Islam wa Adillatubu. Kitab Tafsir al-Munir ini pertama kali diterbitkan pada tahun $1991 \mathrm{M} / 1411 \mathrm{H}$ oleh Dar al-Fikr Beirut Libanon dan Da>r al-Fikr Damaskus Syiria. Dengan demikian, kitab tafsir ini ditulis oleh azZuhaili ketika ia mencapai puncak karir intelektualnya, dan kitab ini banyak diterjemahkan di berbagai negara seperti Malaysia, Turki, dan Indonesia. ${ }^{14}$

Mengacu pada empat metode penafsiran Alquran yang ditawarkan oleh 'Abd al-Hayy al-Farmawi, kitab Tafsir al-Munir ini termasuk mengaplikasikan metode tafsir tablili dalam menafsirkan ayat-ayat Alquran. Namun terkadang azZuhaili juga menggunakan metode tafsir tematik (maudhu') dalam beberapa tempat dengan kapasitas yang sangat sedikit. ${ }^{15}$ Metode tablili lebih dominan karena mayoritas penafsirannya dilakukan secara terperinci dan panjang lebar. Adapun kerangka pembahasan atau sistematika dalam Tafsir al-Munir adalah sebagai berikut:

14 Tujuan utama az-Zuhaili dalam menyusun kitab tafsir ini adalah menjalin ukhuwah yang kuat antara umat Islam dengan al-Qur'an, karena al-Qur'an merupakan petunjuk yang di dalamnya memuat berbagai hukum yang dikhususkan bagi umat Islam dan umat manusia secara universal. Oleh karenanya, az-Zuhaili berusaha menjelaskan hukum-hukum yang terdapat dalam ayat-ayat al-Qur'an dengan cara ber-istinbat secara ekstensif, bukan menjelaskan berbagai hukum fiqih sesuai dengan problematika yang ada dalam sudut pandang para fuqaha. Orientasi penafsiran hukumnya mencakup secara eksplisit maupun implisit tentang akidah dan akhlak, manhaj dan prilaku, konstitusi umum, serta faedah-faedah yang diadopsi dari ayat-ayat al-Qur'an. Lihat dalam muqaddimah, Wahbah az-Zuhaili, al-Tafsir al-Munir., Juz I, 11

15Penafsiran menggunakan metode tafsir tematik yang dilakukan oleh az-Zuhaili terlihat ketika ia menjelaskan ayat-ayat tentang jihad, hudud, waris, nikah, riba, khamr dan masih banyak lagi yang lainnya. Lihat az-Zuhaili, al-Tafsir al-Munir., Juz I, 12. 
1. Menetapkan satu topik pembahasan dari ayat-ayat Alquran dengan memberikan tema yang relevan.

2. Menjelaskan secara global kandungan setiap surah di awal penafsiran.

3. Menjelaskan aspek linguistik.

4. Mencantumkan riwayat asbab al-nuzul ayat yang paling sahih, dan meninggalkan riwayat yang lemah.

5. Menjelaskan cerita-cerita valid yang memiliki korelasi dengan ayat yang hendak ditafsirkan.

6. Menjelaskan ayat-ayat Alquran secara terperinci.

7. Melengkapi pembahasan dengan hadis-hadis relavan dengan pokok bahasan.

8. Mencantumkan hukum-hukum yang sesuai dengan ayat yang ditafsirkan.

9. Mengupas retorika dan sintaksis pada ayat-ayat yang hendak ditafsirkan. ${ }^{16}$

Beberapa metode di atas secara komperhensif menampakkan kompleksitas az-Zuhaili dalam mengkaji ayat-ayat Alquran. Di samping itu, azZuhaili juga memperlihatkan sistematika yang digunakannya termasuk trend dalam kajian paradigma tafsir adabi al-ijtima'i. Bukti konkretnya adalah atensi eksklusif terhadap aspek linguistik dalam penafsiran, sebagaimana terungkap dalam poin ketiga dan kesembilan. Sistematika tafsir terperinci, global dan tematik juga mengindikasikan az-Zuhaili ikut meramaikan trend masa kini, sebagaimana metode yang digagas al-Farmawi. Sementara aspek kedelapan merupakan kontekstualisasi pemahaman az-Zuhaili terkait hukum-hukum yang dideduksi dari ayat-ayat Alquran berdasarkan yurisprudensial.

Dengan demikian, dapat diketahui bahwa corak tafsir yang dipakai azZuhaili adalah corak kesastraan (adabi) dan sosial kemasyarakatan (al-ijtima'i>) yang dikolaborasikan dengan nuansa yurisprudensial (fiqih). Hal ini tampak dengan adanya penjelasan fiqih kehidupan (figh al-hayat) atau hukum-hukum yang terkandung dalam penafsirannya. Secara faktual, az-Zuhaili sendiri memang sangat familiar keahliannya dalam bidang fiqih dengan karya monumentalnya alFigh al-Islam wa Adillatubu, sehingga tidak dapat dipungkiri bahwa corak penafsiran Tafsir al-Munir adalah keselarasan antara adabi al-ijtima'i dan nuansa fiqihnya atau penekanan ijtima'i-nya lebih ke nuansa fiqih.

Berdasarkan sumber penafsirannya, az-Zuhaili memakai perpaduan antara tafsir bi al-ma'tsur dan tafsir bi al-ma'qul, serta menggunakan retorika yang jelas, yakni keterampilan bahasa kontemporer yang mudah dipahami bagi para pembacanya. Sementara itu, sumber-sumber referensi yang digunakan az-Zuhaili dalam Tafsir al-Munir adalah merujuk kepada Tafsir al-Kabir karya Fakhr ad-Din ar-Razi, tafsir Ruh al-Ma'ani karya al-Alusi dan Tafsir al-Babr al-Mubith karya Abu

${ }^{16}$ Az-Zuhaili, al-Tafsir al-Munir., Juz I, 9. 
Hayyan al-Andalusi terkait bidang akidah, akhlak, dan penjelasan kebesaran Allah di alam semesta.

Adapun penjelasan tentang kisah-kisah Alquran dan sejarah, az-Zuhaili merujuk Tafsir al-Khazin dan Ma'alim at-Tanzil karya al-Baghawi. Sedangkan pada Tafsir Alquran al-'Azbim karya Ibnu Katsir dan tafsir al-Kassyaf karya azZamakhsyari, ia gunakan untuk merujuk bidang kebahasaan. Terkait penjelasan hukum-hukum fiqih, az-Zuhaili tidak terlepas dari beberapa literatur klasik seperti al-Jami' li Abkam Alquran karya al-Qurthubi, Abkam Alquran karya Ibn al'Arabi, dan Abkam Alquran karya al-Jashshas. Sementara materi qira'at dirujuk dari Tafsir an-Nasafi, kemudian pada kitab al-Jawabir karya Thanthawi Jauhari, azZuhaili mengutip teori-teori ilmu pengetahuan alam dan Sains, serta masih banyak lagi yang lainnya. ${ }^{17}$

\section{Paradigma Pendekatan Tekstual dan Kontekstual dalam Penafsiran Alquran}

Teks merupakan fiksasi atau pelembagaan sebuah wacana lisan dalam bentuk tulisan. Penggunaan kata teks pada Alquran secara sederhana dapat dipahami sebagai tulisan yang telah sampai kepada kita sebagai pembaca (baca: mushaf), dan fiksasi tulisan dalam mushaf ini bersifat konstitusi terhadap teks itu sendiri. ${ }^{18}$ Pendekatan tekstual dalam studi tafsir merupakan suatu upaya dalam memahami makna tekstual dari ayat-ayat Alquran. Pada pendekatan tekstual, praktik tafsir lebih berorientasi pada teks dalam dirinya. Kontekstual suatu teks lebih dilihat sebagai posisi suatu wacana internalnya atau lazim disebut intrateks.

Pendekatan tekstual ini preferensinya lebih menekankan pada analisis yang bergerak dari refleksi (teks) ke praksis (konteks) yaitu memfokuskan pembahasan pada gramatikal-tekstual. Dalam hal ini, muara praksis lebih bersifat kearaban sehingga pengalaman sosio-historis sang mufasir dengan audiennya hidup dan berkembang sama sekali tidak memiliki peran. Argumentasi ini didukung oleh pendapat bahwa Alquran sebagai kitab sakral memang sudah final dan telah sempurna dengan dirinya sendiri. ${ }^{19}$

Sementara konteks merupakan sebuah situasi yang di dalamnya terdapat suatu peristiwa terjadi atau situasi yang menyertai munculnya sebuah teks;

17 Wahbah az-Zuhaili, al-Tafsir al-Munir, terj. al-Kattani dkk, Juz I, Jakarta: Gema Insani, 2013), xix.

${ }^{18}$ Komarudin Hidayat, Memahami Bahasa Agama: Sebuab Kajian Hermeneutik, Jakarta: Paramadina, 1996), 132-134.

${ }^{19}$ Syahrullah Iskandar, "Studi al-Qur'an dan Integrasi Keilmuan: Studi Kasus UIN Sunan Gunung Djati Bandung,” WAWASAN: Jurnal Ilmiah Agama Dan Sosial Budaya 1, No. 1, (2016) 87. 
sedangkan kontekstual artinya berkaitan dengan konteks tertentu. Definisi kontekstual sendiri secara terminologi memiliki beberapa makna yang berbeda, yaitu: 1) berbagai usaha untuk memahami makna dalam rangka mengantisipasi problem-problem yang muncul pada masa sekarang; 2) makna yang melihat relevansi masa lalu, sekarang dan akan datang; di mana sesuatu akan dilihat dari titik historisitas, makna fungsional sekarang, dan prediksi makna yang relevan di masa yang akan datang; dan 3) memperlihatkan korelasi antara pusat (central) dan pinggiran (periphery), dalam arti bahwa sentral adalah teks Alquran dan periferi adalah terapannya. ${ }^{20}$

Di antara ciri-ciri penafsiran kontekstual ini adalah model tafsirnya memprioritaskan konteks sosio-historis dalam proses penafsirannya. Penjelasan tafsirnya lebih melihat nilai etis dari ketetapan legal Alquran daripada makna literalnya. Berbeda dengan tafsir tekstual yang memiliki preferensi unsur linguistik dan penjelasan riwayat, tafsir kontekstual lebih mencakup terhadap unsur politik, sosial, sejarah, budaya, dan ekonomi dalam upaya memahami sebuah teks. Berbeda pula dengan tafsir tradisionalis yang cenderung teologisfilosofis, tafsir kontekstual orientasinya lebih cenderung ke sosiologis, aksiologis, dan antropologis, karena menyesuaikan dengan kondisi siosial umat Islam di era abad kontemporer. ${ }^{21}$

Pendekatan kontekstual dimaksudkan untuk mencoba menafsirkan Alquran berdasarkan pertimbangan analisis bahasa, latar belakang sejarah, politik, sosiologi, dan antropologi yang berlaku dalam kehidupan masyarakat Arab pra-Islam dan selama proses pewahyuan Alquran berlangsung. Secara substansial, pendekatan kontekstual ini berkaitan dengan pendekatan hermeneutika yang merupakan bagian di antara pendekatan penafsiran teks yang berangkat dari kajian bahasa, sejarah, sosiologi, dan filosofis. ${ }^{22}$ Sehingga untuk menemukan makna ayat-ayat Alquran tidak hanya dipahami dengan pendekatan tekstual semata, tetapi kondisi-kondisi yang terkait dengan turunnya ayat juga menjadi sesuatu yang sangat fundamental dalam memahami ayat-ayat Alquran. Di mana keterlibatan kondisi-kondisi tersebut menjadi titik penting dalam memahami ayat-ayat Alquran dengan menggunakan pendekatan kontekstual.

\footnotetext{
${ }^{20}$ Noeng Muhadjir, Metodologi Penelitian Kualitatif (Yogyakarta: Rake Sarasin, 2000), 263264.

${ }^{21}$ Cucu Surahman, "Tafsir Kontekstual JIL: Telaah atas Konsep Syariat dan Hudud," Journal of Qur'an and Hadith Studies 2, No. 1 (2012), 65-66.

${ }_{22}$ Richard E. Palmer, Hermeneutics: Interpretation Theory in Scbleiermacher, Dilthey, Heidegger, and Gadamer (Evanston: Northwestern University Press, 1969), 34-45. Sebagaimana dikutip M. Solahudin, "Pendekatan Tekstual dan Kontekstual dalam Penafsiran al-Qur'an", AL-BAYAN: Jurnal Studi al-Qur'an dan Tafsir 1, No. 2 (2016), 118.
} 
Dengan demikian, kajian ayat-ayat Alquran secara kontekstual erat hubungannya dengan pemahaman asbab al-nu₹ul ayat. Meskipun realitasnya tidak semua ayat memiliki asbab al-nuzul yang membuat status ayat bersifat umum atau khusus. Oleh karenanya, dengan mengetahui kondisi yang menyebabkan turunnya ayat Alquran akan dapat mudah ditentukan apakah ayat tersebut dapat dipahami dengan pendekatan tekstual ataukah kontekstual. Selain itu, pendekatan kontekstual ini cenderung dilakukan mufasir dalam memahami ayatayat Alquran melalui konteks dari ayat-ayat Alquran itu sendiri, situasi dan kondisi dimana dan karena alasan apa ayat-ayat Alquran itu diturunkan, serta melihat pula konteks penafsir di mana ia hidup dan berada, dengan pengalaman sejarah, sosial, dan budayanya sendiri.

Salah satu contoh representatif dalam penggunaan pendekatan kontekstual ini adalah Farid Esack. Ia menempatkan hermeneutika Alquran dalam ruang sosial di mana ia berada, sehingga sifatnya bukan lagi ke-Araban yang bersifat umum. Esack merumuskan hermeneutika Alquran yang berporos pada pembebasan dan persamaan dengan mempertimbangkan aspek kontekstual di mana ia hidup. Menurut Esack, setiap produk penafsiran tidak akan lepas dari subyektivitas penafsirnya. Dia berasumsi bahwa setiap orang mendatangi teks dengan persoalan sendiri tanpa untuk menuntut penafsir lepas sepenuhnya dari subyektivitas dirinya. Dengan kata lain, penafsiran suatu teks tidak akan terpahami tanpa dipengaruhi pemahaman awal yang berada dalam benaknya. ${ }^{23}$ Ini artinya penafsiran Alquran yang dikehendaki Esack bagaimana pun dipaksa memasukkan wacana asing ke dalam proses memahami Alquran.

\section{Diskursus Penafsiran Tekstual Wahbah az-Zuhaili terkait Ayat- ayat Gender}

Wahbah az-Zuhaili sebagai salah satu mufasir periode kontemporer, ternyata mengaplikasikan model penafsirannya dengan merujuk pada beberapa riwayat. Terkait ayat-ayat yang membicarakan perempuan, az-Zuhaili cenderung menafsirkan secara tekstual dan tidak seluruhnya dijelaskan dengan rinci, bahkan terkadang dijelaskannya dengan singkat dan padat. Agar tulisan ini lebih fokus, penulis menyoroti dan membatasi pembahasan topik yang telah menjadi pembicaraan utama dan populer dalam kajian ayat-ayat gender, di antaranya tentang:

\section{Asal Mula Penciptaan Perempuan}

Sebagai salah satu spesies makhluk biologis, manusia asal mulanya berasal dari tanah. Laki-laki dan perempuan dalam hal ini belum ada distingsi yang signifikan, baik secara substansial maupun struktural. Dalam proses

${ }^{23}$ Ahmad Zainal Abidin, “Epistemologi Tafsir al-Qur'an Farid Esack,” THEOLOGIA 24, No. 1 (2013), 12. 
eksistensi keduanya masih sederajat. ${ }^{24}$ Alquran juga menyebutkan proses penciptaan manusia dilakukan melalui proses reproduksi. Dalam proses reproduksi pun juga belum ditemukan distingsi secara khusus antara laki-laki dan perempuan. ${ }^{25}$ Oleh karenanya, proses dan mekanisme biologis tentang penciptaan manusia tidak memberikan celah sebagai alasan yang kuat untuk mengenyampingkan salah satu dari keduanya, laki-laki atau perempuan.

Lebih lanjut, tentang siapa di antara Adam dan Hawa yang lebih dulu diciptakan, ataukah diciptakan secara bersamaan, Alquran tidak menyebutkan secara spesifik. Namun para mufasir klasik maupun kontemporer sepakat bahwa manusia pertama yang diciptakan adalah Adam, bukan Hawa. Terlepas dari penciptaan Adam dan Hawa, terdapat empat ayat dalam empat surah berbeda yang mengisyaratkan tentang penciptaan perempuan, yaitu QS. an-Nisa' [4]: 1, QS. al-An'am [6]: 98, QS. al-A'raf [7]: 189, dan QS. al-Zumar [39]: 6. Konklusi yang ditangkap tentang penciptaan perempuan dalam empat surah tersebut menegaskan, bahwa manusia baik laki-laki maupun perempuan diciptakan dari ungkapan kata nafsin wahidah, sebagaimana ungkapan ayat berikut ini:

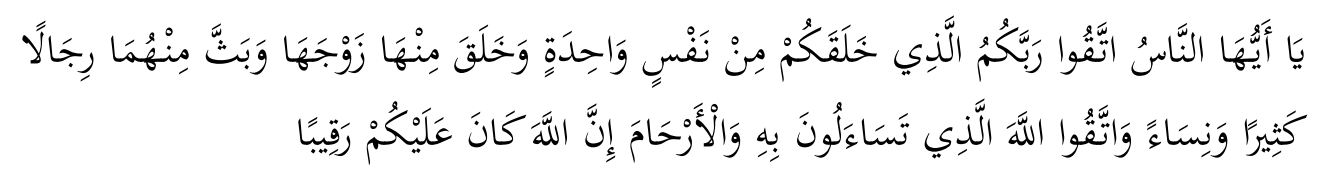

"Hai sekalian manusia, bertakwalah kepada Tuban-mu yang telab menciptakan kamu dari seorang diri, dan dari padanya Allah menciptakan isterinya; dan dari pada keduanya Allah memperkembang-biakekan laki-laki dan perempuan yang banyak. Dan bertakwalah kepada Allah yang dengan (mempergunakan) nama-Nya kamu saling meminta satu sama lain, dan (peliharalah) bubungan silaturrabim. Sunggub Allah selalu menjaga dan mengawasi kamu" (QS. an-Nisa' [4]: 1).

Pada ayat ini, Wahbah az-Zuhaili menafsirkan kata nafsin wabidah cenderung secara tekstual. Ia memahami bahwa Adam adalah manusia pertama yang diciptakan oleh Allah, sementara Hawa merupakan manusia kedua yang diciptakan dari tulang rusuk sebelah kiri dari tubuh Adam. Penafsiran az-Zuhaili ini dapat dibaca ketika ia memahami redaksi wa khalaqa minha zaujaha. ${ }^{26} \mathrm{Az}-$

${ }^{24}$ Manusia berasal dari tanah dapat dilihat dalam QS. Nuh [71]: 17-18, QS. Thaha [20]: 55, QS. Hud [11]: 61, QS. al-H\{ajj (22): 5, QS. as-Shaffat [37]: 11, QS. al-Rahman [55]:14, QS. al-Hijr [15]: 26 dan 28-29, QS. al-Mu'minun [23]: 12, QS. an-Nisa' [4]: 1, QS. al-A'raf [7]: 11, QS. al-Infithar [82]: 7-8, dan QS. at-Tin [95]: 4.

${ }_{25}$ Penciptaan manusia melalui reproduksi disebutkan dalam QS. al-Qiyamah [75]: 37, QS. al-Insan [76]: 2, QS. as-Sajdah [32]: 8, dan QS. al-Mu'minun [23]: 14.

${ }^{26} \mathrm{Az}$-Zuhaili, al-Tafsir al-Munir., Juz IV, 555. 
Zuhaili memperkuat penafsirannya ini dengan mencantumkan hadis Nabi yang diriwayatkan al-Bukhari dan Muslim sebagai berikut:

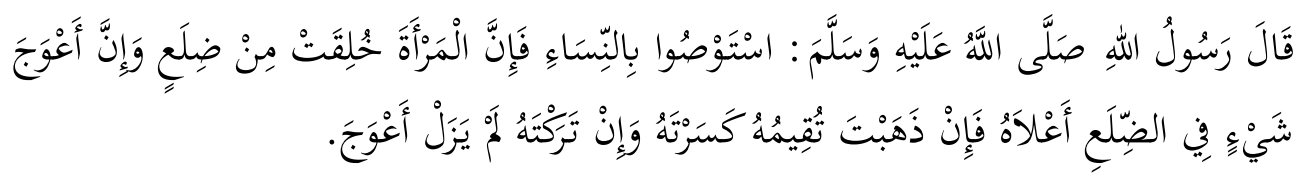

'Pergaulilab kaum perempuan dengan baik, karena sesunggubnya mereka diciptakan dari tulang rusuk. Sesuatu yang paling bengkok yang terdapat pada tulang rusuk adalah bagian paling atas. Jika kamu meluruskannya dengan seketika niscaya kamu akan mematahkannya, namun jika kamu membiarkannya maka ia pun akan selalu dalam keadaan bengkok."

Meski demikian, penafsiran berbeda tetap diungkapkan az-Zuhaili dengan mencantumkan pendapat Abu Muslim al-Ashfahani yang cenderung memahami ayat tersebut pada proses reproduksi. Al-Ashfahani menandaskan bahwa laki-laki dan perempuan memang dua jenis kelamin yang berbeda namun berasal dari satu usur, satu jenis dan satu tabiat, kedunya harus saling mendukung dan menyempurnakan. Konteks penafsiran ini dikomentari kemudian oleh az-Zuhaili bahwa ia tetap bersikukuh pada landasan hadis sahih yang dikutipnya. Ia menyatakan bahwa Hawa diciptakan dari tulang rusuk Adam merupakan sebuah hikmah atas kekuasaan dan kebesaran Allah yang mampu menciptakan makhluk hidup, bukan hanya dari makhluk yang hidup, tetapi juga dari benda mati. ${ }^{27}$

Ayat kedua yang mengulas tentang nafsin wabidah adalah QS. al-An'am [6]: 98. Az-Zuhaili menafsirkan kata ini dengan arti Adam yang darinya diciptakan manusia baik laki-laki ataupun perempuan. Adam disinyalir sebagai bapak dari semua manusia di dunia dan tidak ada manusia yang wujud pertama kecuali Adam. Ia merujuk kembali penafsirannya pada QS. an-Nisa' [4]: $1{ }^{28} \mathrm{Hal}$ ini mengandung arti bahwa asal mula manusia adalah Adam, termasuk perempuan yang menurut pendapat mayoritas mufasir diciptakan dari tulang rusuk sebelah kiri dari laki-laki. ${ }^{29}$

Lebih jauh, az-Zuhaili menafsirkan kata setelah nafsin wa> blidah yakni $f a$ mustaqar wa mustawda' dengan arti tempat menetapnya sperma yaitu tulang sulbi

${ }^{27}$ Az-Zuhaili, al-Tafsir al-Munir., Juz IV, 556-557.

${ }^{28}$ Az-Zuhaili, al-Tafsir al-Munir., Juz VIII, 325.

${ }^{29}$ Lihat di antaranya: Muhammad Fakhr ad-Din ar-Razi, Tafsir al-Kabir wa Mafatih alGhaib, Juz IX, (Beirut: Dar al-Fikr, t.th), 166. Nashiruddin as-Syairazi al-Baidhawi, Anwar atTanzil wa Asrar at-Ta'wil bi Tafsir al-Baidhawi, Juz II, (Beirut: Dar Ihya' al-Turats al-'Arabi, t.th), 58. Abu al-Fida’ Ibn Katsir, Tafsir al-Qur'an al-'Azhim, Juz II, (Beirut: Dar al-Kutub al-'Tlmiyah, 1998), 181. Muhammad 'Abd al-Haq bin Ghalib Ibn 'Atiyyah al-Andalusi, al-Mubarrar al-Waji fi Tafsir al-Kitab al-Aziæ, Juz II, (Beirut: Da>r al-Kutub al-'Ilmiyah, 2001), 4. 
pada laki-laki dan tempat bersemayamnya sperma yaitu dirahim perempuan. ${ }^{30}$ Ini membuktikan bahwa penafsiran yang dikehendaki az-Zuhaili setelah memastikan nafsin wabidah sebagai unsur pertama yang darinya diciptakan lakilaki dan perempuan, ia seakan menyatakan adanya proses reproduksi dengan dianugerahinya unsur pertama melalui penetapan sperma (mustawada) pada sulbi laki-laki (al-rijal), kemudian diletakkan dan ditetapkannya sperma (mustaqar) dirahim perempuan (al-nisa) (baca: proses reproduksi).

Kemudian ayat ketiga yang mengulas tentang nafsin wabidah adalah QS. al-A'raf [7]: 189. Pada ayat ini, az-Zuhaili tidak memberi penafsiran berbeda dengan QS. an-Nisa' [4]: 1. ${ }^{31}$ Ia merujuk kembali pada penafsiran sebelumnya dan menganggap ayat ini memiliki kemiripan dalam segi kandungan maknanya. Sedangkan ayat keempat yang membahas tentang nafsin wabidab adalah QS. alZumar [39]: 6. Terkait dengan ayat ini, az-Zuhaili menegaskan kembali bahwa Adam adalah manusia pertama yang diciptakan. Kemudian az-Zuhaili menjelaskan tiga poin penting dari kandungan kata setelah nafsin wabidah, yaitu wa ja'ala minha zaujaba; (1) Adam diciptakan pertama kali tanpa seorang bapak dan ibu, (2) penciptaan Hawa tidak dari tulang rusuk Adam, melainkan sama dengan penciptaan Adam yaitu berasal dari jenis yang satu (nafsin wabidah), dan (3) seluruh manusia di dunia berasal dari Adam dan Hawa. ${ }^{32}$ Berdasarkan pada penafsiran ini, meski manusia berasal dari dua pasangan, laki-laki dan perempuan, bapak dan ibu, Adam dan Hawa, namun mereka berasal dari unsur satu yaitu nafsin wahidah.

Dari penafsiran di atas, dapat dipahami bahwa dari keempat ayat tersebut, az-Zuhaili ketika menafsirkan ayat gender yang berkaitan dengan penciptaan perempuan, terutama yang terkait dengan nafsin wahidah, ia selalu menyinggung dalam penafsirannya bahwa Adam dianggap sebagai manusia pertama dan Hawa sebagai manusia kedua yang berasal dari salah satu tulang rusuk Adam. Namun dalam hal penciptaan Hawa atau perempuan tersebut, ia juga mencantumkan pendapat bahwa Hawa tidak diciptakan dari tulang rusuk Adam, melainkan dari jenis yang sama dengan Adam. Dengan demikian, tidak menutup kemungkinan bahwa penciptaan perempuan dari salah satu tulang rusuk Adam adalah sebuah mitos, sementara pendapat yang menegaskan bahwa perempuan tercipta dari jenis yang sama dengan Adam adalah fakta, meskipun tidak dapat dipungkiri bahwa mayoritas pakar tafsir sepakat dengan penciptaan perempuan berasal dari tulang rusuk sebelah kiri dari laki-laki.

30 Az-Zuhaili, al-Tafsir al-Munir., Juz VIII, 325.

${ }^{31}$ Az-Zuhaili, al-Tafsir al-Munir., Juz IX, 212.

32 Az-Zuhaili, al-Tafsir al-Munir., Juz XIII, 271. 


\section{Formula Waris 1:2 Bagi Perempuan}

Dalam konteks pembahasan ini, problematika warisan dalam Alquran secara representatif dapat dilihat pada QS. an-Nisa' [4]: 11-12. Ayat ini secara implisit menjelaskan tentang pembagian warisan - harta peninggalan mayit, yaitu; bagian seorang anak laki-laki sama dengan bagian dua orang anak perempuan; dan jika anak itu semuanya perempuan lebih dari dua, maka bagi mereka dua pertiga dari harta yang ditinggalkan secara kolektif. Jika anak perempuan itu seorang saja, maka ia memperoleh separuh harta.

Kemudian untuk dua orang bapak-ibu, bagi masing-masingnya seperenam dari harta yang ditinggalkan apabila orang yang meninggal itu mempunyai anak. Namun jika orang yang meninggal tidak mempunyai anak dan ia diwarisi oleh bapak-ibunya saja, maka ibunya mendapatkan sepertiga. Sementara jika yang meninggal itu mempunyai beberapa saudara, maka ibunya mendapat seperenam. Pembagian-pembagian tersebut di atas dapat direalisasikan manakala sudah dipenuhi wasiat yang dibuat si mayit atau sesudah dibayar hutangnya. Allah kemudian menutup firman-Nya dengan sebuah pernyataan, bahwa pembagian waris ini berdasarkan ketetapan Allah yang mengatur sedemikian rupa dan rigid tentang kewarisan.

Az-Zuhaili dalam menafsirkan QS. an-Nisa' [4]: 11-12 ini memulai dengan penjelasan dua asbab al-nuzul yang dikutipnya. Pertama, merujuk pada hadis yang dikeluarkan kutubus sittah dari Ja>bir bin 'Abdullah. Dikatakan bahwa Nabi Muhammad bersama Abu Bakr menjenguk Jabir dengan berjalan kaki ketika Jabir sakit di kota Bani Salamah. Beliau mendapatkan Jabir dalam keadaan pingsan. Lalu beliau meminta air kemudian berwudhu dengan air itu, setelah itu beliau memerciki Ja>bir hingga dia pun sadar kembali. Lalu Jabir bertanya; Ya Rasulullah, apa yang engkau perintahkan kepadaku mengenai hartaku setelah aku meninggal? Kemudian turunlah QS. an-Nisa' [4]: 11-12.

Kedua, hadis yang dikeluarkan Ahmad, Abu Dawud, at-Tirmidzi dan alHakim dari Jabir. Dijelaskan bahwa suatu hari istri Sa'ad bin ar-Rabi' datang kepada Nabi beserta kedua putrinya, dia berkata: "Wahai Rasulullah, ini adalah kedua putrinya Sa'ad bin ar-Rabi' yang telah mati syahid pada perang Uhud bersamamu dan sungguh pamannya mengambil seluruh harta warisannya." Kemudian turunlah QS. an-Nisa' [4]: 11-12. Lalu Nabi menyuruh pamannya untuk menyerahkan dua pertiga harta warisan kepada kedua putri Sa'ad, untuk istrinya seperdelapan, dan sementara pamannya mengambil sisanya. ${ }^{33}$

Selanjutnya az-Zuhaili menjelaskan tradisi pewarisan masyarakat Arab pra Islam yang dapat diideintifikasi pada tiga sebab. Pertama, berdasarkan keturunan (al-nasab), yaitu pewarisan yang berhak menerimanya hanya anak laki-

${ }^{33}$ Az-Zuhaili, al-Tafsir al-Munir., Juz IV, 606. 
laki yang telah mampu berperang dan membunuh musuh. Sementara kaum perempuan dan anak laki-laki yang masih kecil tidak berhak untuk mendapatkan jatah harta warisan. Kedua, berdasarkan pengangkatan anak (al-tabani), yaitu memposisikan anak angkat sejajar dengan anak kandung dalam hal penerimaan warisan, dan ketiga, berdasarkan pada sumpah dan ikrar (al-bilf wa al-abd), yaitu seseorang yang bersumpah kepada orang lain, semisal dengan mengatakan: "darahku adalah darahmu, kehancuranku adalah kehancuranmu, kamu mewarisiku dan aku akan mewarisimu dan kamu akan melindungiku sebagaimana aku melindungimu". Seiring perkembangan Islam, akhirnya Islam memfinalkan tiga bentuk sebab pewarisan saja, yaitu karena faktor keturunan (alnasab), faktor pernikahan (al-zawaj), dan faktor memerdekakan budak (al-wala'). ${ }^{34}$

Lebih lanjut, penafsiran yang umum dibahas pada QS. an-Nisa' [4]: 1112 ini adalah bagian waris untuk perempuan setengah dari bagian waris untuk laki-laki. Ini setidaknya dapat dijumpai dalam beberapa penafsiran klasik seperti at-Thabari, ${ }^{35}$ al-Baidhawi ${ }^{36}$, ar-Razi, dan lainnya. Pakar tafsir ar-Razi misalnya, menyatakan ada empat alasan mengapa perempuan hanya mendapat bagian setengah dari laki-laki; pertama, semua kebutuhan perempuan secara komplit dilengkapi oleh laki-laki, karena laki-laki wajib memberikan nafkah pada perempuan; kedua, laki-laki lebih sempurna dalam hal penciptaan, intelektual, dan segi religiusnya daripada perempuan; ketiga, intelektual perempuan lebih rendah dan syahwatnya lebih tinggi dari laki-laki, sehingga jika dicukupi dengan harta yang lebih dapat menimbulkan perilaku destruktif dalam kehidupannya; dan keempat, laki-laki memiliki kesempurnaan intelektual, sehingga dengan mudah mengoperasionalkan hartanya untuk alokasi yang lebih bermanfaat di dunia maupun di akhirat. ${ }^{37}$

Kemudian dalam pandangan az-Zuhaili, laki-laki mendapatkan bagian dua kali lebih besar daripada perempuan adalah karena lak-laki berkewajiban memberikan nafkah pada istri, memberikan mahar maskawin, dan menanggung kesulitan dalam bekerja. Hal ini tentu tidak berlaku pada kaum peremupuan, baik untuk anak perempuan, saudara perempuan, ibu, istri maupun bibi. Mereka semua tidak diwajibkan untuk menafkahkan hartanya bagi kepentingan dirinya ataupun kebutuhan yang lainnya. Az-Zuhaili kemudian tidak menyikapi lebih lanjut tentang penafsirannya tersebut. Ia sama sekali tidak menyinggung tentang

\footnotetext{
${ }^{34}$ Az-Zuhaili, al-Tafsir al-Munir., Juz IV, 607.

${ }^{35}$ Muhammad Ibn Jarir at-Thabari, Jami' al-Bayan 'An Ta'wil Ay al-Qur'an, ed. 'Abd alMuhsin at-Turk>, Juz VI, (Kairo: Dar Hijr, 2001), 456.

36 Al-Baidhawi, Anwar at-Tan₹il wa Asrar at-Ta'wil., 62.

${ }^{37}$ Ar-Razi, Tafsir Kabir wa Mafatih al-Ghaib, Juz IX, 214.
} 
sejarah bagaimana perempuan bisa mendapatkan warisan dengan formula yang seolah timpang. ${ }^{38}$

Namun demikian, penafsiran yang ditawarkan az-Zuhaili ini sejatinya mengacu pada tekstual ayat yang lain ${ }^{39}$ bahwa kehidupan dalam rumah tangga, laki-laki (suami) memiliki tugas dan tanggung jawab lebih besar daripada perempuan (istri), sehingga berimplikasi pada pembagian harta warisan, di mana laki-laki mendapatkan dua bagian dan perempuan hanya mendapat satu bagian. Az-Zuhaili tampaknya mendukung ajaran Islam yang rigid dengan tujuan agar perekonomian tetap stabil dan kemashlahatan universal tetap eksis. Jika menurutnya kewajiban menafkahi perempuan adalah murni kewajiban laki-laki, tampaknya alasan formula waris 1:2 bagi perempuan yang disepakatinya memang murni karena hal tersebut, dan formula ini tidak timpang serta dianggap adil.

\section{Kepemimpinan Perempuan dalam Rumah Tangga}

Dalam konstelasi sejarah sosiologis-kultural, kaum perempuan disinyalir sebagai manusia nomor dua setelah laki-laki, sehingga timbul persepsi bahwa perempuan hanya sekedar pembantu dan komplemen. Persepsi ini dapat dijumpai pada sejarah perempuan ketika tidak memiliki arti fundamental pada masa pra-Islam. Sejumlah persepsi negatif sampai saat ini masih terbilang cukup kuat pada diri perempuan, seperti perempuan sangat lemah, emosional, dan irrasional, sehingga lahir justifikasi perempuan yang perannya hanya cocok dalam dunia domestik -mengurusi rumah tangga dan tidak layak menjadi pemimpin- serta tidak bernilai ekonomi dan sosial. Bahkan persepsi negatif ini tidak sedikit dilegitimasi dengan memandang sebagai pesan teologis. ${ }^{40}$

Kemudian dengan kemajuan IT (informasi teknologi), perkembangan yang dicapai kaum perempuan pun melambung kencang. Dari yang sebelumnya hanya ber-operasional pada area domestik, sekarang menjajah ke dunia yang lebih luas, baik dalam bidang pendidikan, sosial, ekonomi, maupun politik. Namun demikian, tidak dapat dipungkiri bahwa laki-laki atau suami adalah penanggung jawab utama atas segala keputusan keluarga. Selain alasan karena laki-laki yang menafkahi keluarga, juga karena sejauh ini pemahaman atas tafsir Alquran pun berkembang dan menjustifikasi problema ini. Dalil Alquran yang paling sering dirujuk untuk masalah kepemimpinan adalah QS. an-Nisa' [4]: 34:

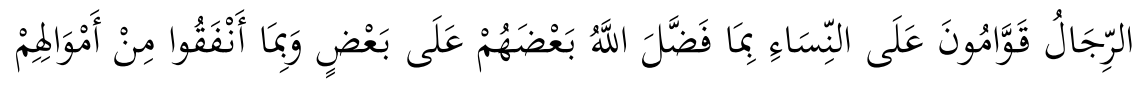

${ }^{38}$ Az-Zuhaili, al-Tafsir al-Munir., Juz IV, 608.

${ }^{39}$ Lihat, QS. an-Nisa' [4]: 34.

40 Tasbih, "Urgensi Pemahaman Kontekstual Hadis (Refleksi terhadap Wacana Islam Nusantara)," AL-ULUM 16, No. 1 (2016), 95-96. 
"Laki-laki itu pemimpin bagi kaum wanita, karena Allah telah melebibkan sebahagian mereka (laki-laki) atas sebahagian yang lain (wanita), dan karena mereka (laki-laki) telah menafkabkan sebagian dari harta mereka."

Pada ayat ini, lafadz qawwam dalam perspektif mayoritas mufasir secara umum dipahami dengan arti atasan, pemimpin, penguasa, penanggung jawab dan pendidik. Pemahaman seperti ini diutarakan oleh sebagian tafsir klasik seperti ar-Razi dan az-Zamakhsyari. Mereka mengatakan bahwa kelebihan yang dimiliki kaum laki-laki atas kaum perempuan adalah karena keunggulan intelektual dan fisiknya.

Sebagai contoh, ar-Razi mengatakan bahwa laki-laki memang sudah ditetapkan oleh Allah sebagai pemimpin dan penanggung jawab bagi perempuan. Menurutnya ada dua alasan mendasar, pertama, karena laki-laki memiliki kelebihan dari perempuan berupa intelektual dan kemampuan fisik. Kedua, karena laki-laki berkewajiban memberi nafkah dan mahar maskawin bagi istrinya. ${ }^{41}$ Sementara az-Zamakhsyari menyatakan tidak jauh berbeda, bahwa laki-laki adalah pemimpin bagi perempuan, bisa memerintah dan melarangnya sebagaimana perintah dan larangan seorang pemimpin terhadap rakyatnya. Hal ini bukan karena alasan kebiasaan, diskriminasi dan paksaan, melainkan karena kelebihan yang diberikan oleh Allah tehadapnya. ${ }^{42}$

Kemudian dalam penafsiran az-Zuhaili, ia memulainya dengan asbab alnu₹ul yang berkenaan dengan perkataan Hasan al-Bashri, bahwa ada seorang wanita yang mendatangi dan mengadu kepada Nabi kalau suaminya telah menamparnya. Kemudian Nabi bersabda, "Qishash (balaslah)". Lalu Allah menurunkan QS. an-Nisa' [4]: 34 ini. $^{43}$

Selanjutnya makna qawwam pada ayat tersebut diartikan oleh az-Zuhaili sebagai laki-laki (suami) yang dapat memerintah perempuan (istri), melindungi, mengarahkan pada kebenaran, dan mengatur kedisiplinannya. Dengan kata lain, suami adalah pemimpin yang memiliki peran sebagai presiden terhadap istrinya dalam menjalankan urusan rumah tangga. Az-Zuhaili kemudian menggariskan dua alasan mengapa laki-laki dianggap sebagai pemimpin bagi perempuan;

1. Keadaan fisik yang sempurna penciptaannya, bahwa laki-laki dipenuhi dengan persepsi, intelektual, emosional yang moderat, dan terbentuk komplit. Dalam hal ini, laki-laki lebih unggul dari perempuan dalam hal intelektual, argumentasi, tekad dan kekuatan. Oleh karenanya, laki-laki memiliki

${ }^{41}$ Ar-Razi, Tafsir Kabir wa Mafatih al-Ghaib, Juz X, 91.

42 Abu al-Qasim Mahmud bin 'Umar al-Zamakhsyari, Tafsir al-Kasysyaf 'an Haqaiq alTanzil wa 'Uyun al-Aqawal fi Wujuh al-Ta'wil, (Beirut: Dar al-Ma'rifah, 2009), Cet. III, 234.

43 Az-Zuhaili, al-Tafsir al-Munir., Juz V, 57. 
kekhususan seperti menjadi Nabi, menyampaikan risalah, imam besar, juga perceraian harus atas persetujuannya, boleh berpoligami, dan masih banyak lagi yang lainnya.

2. Laki-laki berkewajiban memberi nafkah terhadap istri dan kerabat, serta memberi mahar maskawin sebagai simbol kehormatan bagi perempuaan. Selain itu, laki-laki dan perempuan porsinya sama dalam hak dan kewajiban, dan ini merupakan salah satu keutamaan Islam, sebagaimana disebutkan dalam QS. al-Baqarah [2]: 228 bahwa dalam pengelolaan rumah dan pengawasan urusan keluarga, semuanya sepadan dengan kemampuan laki-laki untuk memikul tanggung jawab dan beban hidup. Namun perempuan memiliki kewajiban finansial independen dan kebebasan penuh dalam kekayaannya.

Makna qawwam dalam pandangan az-Zuhaili ini tampaknya bisa dipahami lebih mudah pada lanjutan ayat, yakni kata shalihat. Dalam penafsirannya, azZuhaili menjelaskan bahwa perempuan salehah itu yang senantiasa taat terhadap suami, tidak melakukan perselingkuhan, dapat menjaga kewibawaan dan harga diri suami, mampu merawat dan memberikan pendidikan bagi anak-anak, serta bisa mengoperasionalkan kebutuhan harta rumah tangga dan apapun yang dimiliki suami. ${ }^{44}$

Dari penafsiran tersebut, telah tampak bagaimana fungsi dan pembagian peran suami-istri dalam urusan rumah tangga. Sepintas, penafsiran az-Zuhaili ini seolah menunjukkan bias patriarki ketika memposisikan perempuan sebagai nomor dua dan komplemen setelah laki-laki. Namun secara hakikat, penafsiran ini susuai dengan nilai-nilai keIslaman yang sudah mengakar sejak masa Rasulullah. Peran yang diidealkan untuk istri adalah seperti menjadi manajer dalam rumah tangga, pendukung karir suami, serta menjadi istri yang taat kepada suami. Sedangkan peran ideal untuk laki-laki adalah pencari nafkah keluarga, penanggung jawab, pelindung, menjaga sekaligus mengayomi dengan status sebagai kepala keluarga. Secara tekstual, penafsiran yang diutarakan az-Zuhaili ini sejalan dengan hadis Nabi berikut ini:

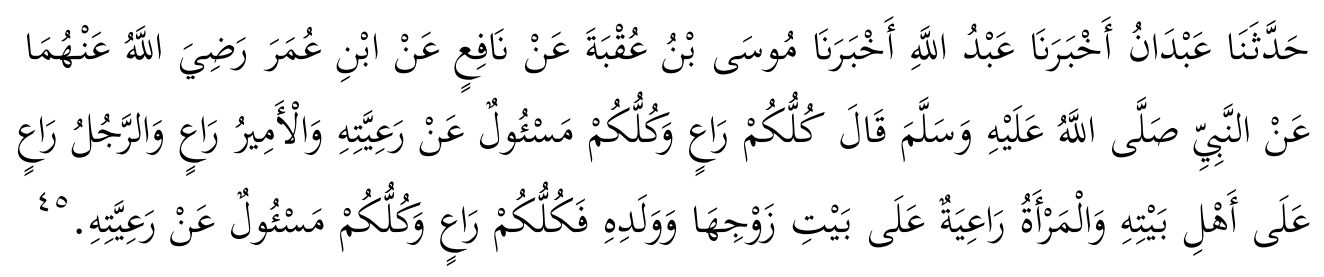

44 Az-Zuhaili, al-Tafsir al-Munir., Juz V, 58.

${ }^{45}$ Muhammad bin Isma'il Abu 'Abdullah al-Bukhari, Shabih al-Bukhari, Juz II, (CD Room: al-Maktabah as-Syamilah, Digital), Hadis no: 893. 
"Rasulullah bersabda: "Setiap kalian adalah pemimpin, dan setiap kalian akan dimintai pertanggungjawaban terbadap apa yang dipimpinnya. Raja adalab pemimpin, dan suami juga pemimpin bagi anggota keluarganya. Adapun istri merupakan pemimpin terhadap rumah suami dan anaknya. Maka setiap kalian adalah pemimpin, dan setiap pemimpin akan dimintai pertanggungjawaban atas apa yang dipimpinnya."

Pada hadis ini, suami dan istri disebutkan memiliki peran masing-masing sesuai dengan kompetensi dan kapabilitasnya. Laki-laki adalah pemimpin anggota keluarganya, sementara perempuan pemimpin atas rumah suami dan anaknya. Dari sini dapat dipahami bahwa perempuan memiliki peran penting dalam mewujudkan rumah tangga bagai istana, karena secara umum istri yang paling otoritatif dalam mengatur rumah tangga. ${ }^{46}$ Dengan demikian, tidak berlebihan jika kepemimpinan perempuan dianggap nomor dua setelah laki-laki dalam mengatur urusan keluarga atau rumah tangga.

Dari ketiga tema tentang penafsiran ayat-ayat gender di atas, tampaknya az-Zuhaili lebih berpegang pada sumber tafsir klasik yang cenderung menafsirkan ayat Alquran dengan cara tekstual. Seharusnya, dengan mengacu pada masa kehidupannya yang termasuk pada zaman kontemporer, az-Zuhaili berupaya mengikuti arus perkembangan zaman sebagaimana mufasir yang serumpun dengannya. Banyak para mufasir kontemporer telah berusaha melakukan penafsiran terhadap Alquran dengan dalih pembaharuan terkait ayatayat gender, dan penafsirannya berhasil tidak bias gender. Namun az-Zuhaili dengan representasi karya Tafsir al-Munir ini, berusaha memadukan orisinalitas tafsir klasik dan keindahan tafsir kontemporer. Ia dalam karyanya banyak mengadopsi tafsir klasik yang cenderung tekstual dengan dikemas ke-bahasa kontemporer. Wa al-basil, buah penafsirannya terkait tema gender tampak bias, dan dianggap tidak selaras dengan tuntutan dan perkembangan zaman.

\section{Kesimpulan}

Pembahasan yang relatif singkat dari tulisan ini menghasilkan kesimpulan, bahwa penafsiran ayat-ayat yang berkaitan dengan kesetaraan gender, Wahbah az-Zuhaili dalam karyanya Tafsir al-Munir menggunakan pendekatan tekstual ayat. Ia tampaknya mengapresiasi dan menyetujui status dan peran perempuan yang telah dijelaskan dalam Alquran. Hal ini dapat dijumpai dari ketiga contoh penafsiran az-Zuhaili terkait ayat gender, yaitu asal mula penciptaan perempuan, formula waris 1:2 bagi perempuan, dan kepemimpinan

${ }^{46}$ Eko Zulfikar, "Peran Perempuan Dalam Rumah Tangga Perspektif Islam: Kajian Tematik Dalam al-Qur'an Dan Hadis”, DIYA AL-AFKAR: Jurnal Studi al-Quran dan al-Hadis 7, No. 1 (2019), 89. 
perempuan dalam rumah tangga. Untuk contoh penafsiran pertama (asal mula penciptaan perempuan), az-Zuhaili tampaknya sepakat dengan kesetaraan gender. Namun dalam persoalan formula waris 1:2 dan kepemimpinan perempuan dalam rumah tangga, penafsirannya tampak mengandung unsur marginalisasi (pemiskinan) dan subordinasi (perempuan itu lebih rendah daripada laki-laki) terhadap perempuan. Namun pandangan az-Zuhaili ini sesuai dengan tekstual ayat, bahwa penafsirannya mengakomodir tradisi yang berlaku bagi laki-laki dan perempuan, yaitu laki-laki sebagai pemberi nafkah keluarga dan perempuan dengan tugas domestiknya yang berimplikasi pada bentuk formula waris 1:2 bagi perempuan.

\section{Bibliografi}

Abidin, Ahmad Zainal. "Epistemologi Tafsir Alquran Farid Esack". THEOLOGIA 24, No. 1 (2013).

Al-Andalusi, Muh \}ammad 'Abd al-H \{aq bin Ghalib Ibn 'Atiyyah. al-Muharrar alWajiz fi Tafsir al-Kitab al-Azi‡. Beirut: Dar al-Kutub al-'Tlmiyah, 2001.

Al-Baidhawi, Nashiruddin as-Syairazi. Anwar at-Tanzil wa Asrar at-Ta'wil bi Tafsir al-Baidhawi. Beirut: Dar Ihya' at-Turats al-'Arabi, t.th.

Baihaki. "Studi Kitab Tafsir al-Munir Karya Wahbah az-Zuhaili dan Contoh Penafsirannya tentang Pernikahan Beda Agama". ANALISIS 16, No. 1 (2016).

Al-Bukhari, Muh \}ammad bin Isma'il Abu 'Abdullah. Shabih al-Bukhari. CD Room: al-Maktabah as-Syamilah, Digital.

Fakih, Mansour. "Posisi Perempuan dalam Islam; Tinjauan dari Analisis Gender", dalam Membincang Feminisme, Diskursus Gender Perspektif Islam. Surabaya: Risalah Gusti, 1996.

Ghafur, Saiful Amin. Mozaik. Mufasir Alquran dari Klasik Hingga Kontemporer. Yogyakarta: Kaukaba, 2013.

Http://www.hidayatullah.com/berita/internasional/read/2015/08/09/75463/ ulama kontemporer-dunia-syeikh-wahbah-zuhaili-berpulang.html. Diakses selasa, 12 November 2018.

Hidayat, Komarudin. Memahami Bahasa Agama: Sebuah Kajian Hermeneutik. Jakarta: Paramadina, 1996.

Iskandar, Syahrullah. "Studi Alquran dan Integrasi Keilmuan: Studi Kasus UIN Sunan Gunung Djati Bandung". WAWASAN: Jurnal Ilmiah Agama Dan Sosial Budaya 1, No. 1 (2016).

Iyazi, Muhammad 'Ali. al-Mufassirun Hayatubum wa Manhajubum. Teheran: Muassasah at-Thiba'ah wa al-Irsyad al-Islami, 1993. 
Katsir, Abu al-Fida' Ibn. Tafsir Alquran al-Azhim. Beirut: Dar al-Kutub al'Ilmiyah, 1998.

Muhadjir, Noeng. Metodologi Penelitian Kualitatif. Yogyakarta: Rake Sarasin, 2000.

Ar-Razi, Muhammad Fakhr ad-Din. Tafsir al-Kabir wa Mafatih al-Ghaib. Beirut: Dar al-Fikr, t.th.

Surahman, Cucu. "Tafsir Kontekstual JIL: Telaah atas Konsep Syariat dan Hudud". Journal of Qur'an and Hadith Studies 2, No. 1 (2012).

Solahudin, M. "Pendekatan Tekstual dan Kontekstual dalam Penafsiran Alquran". AL-BAYAN: Jurnal Studi Alquran dan Tafsir 1, No. 2 (2016).

At-Thabari, Muhammad Ibn Jarir. Jami' al-Bayan 'An Ta'wil Ay Alquran, ed. 'Abd al-Muhsin at-Turki. Kairo: Dar Hijr, 2001.

Tasbih. "Urgensi Pemahaman Kontekstual Hadis (Refleksi terhadap Wacana Islam Nusantara)”. AL-ULUM 16, No. 1 (2016).

Az-Zamakhsyari, Abu al-Qasim Mahmud bin 'Umar. Tafsir al-Kasysyaf'an Haqaiq at-Tanqil wa 'Uyun al-Aqawal fi Wujub at-Ta'wil. Beirut: Dar al-Ma'rifah, 2009.

Az-Zuhaili, Wahbah. al-Tafsir al-Munir fi al-'Aqidah wa as-Syari'ah wa al-Manbaj. Damaskus: Dar al-Fikr, 2006. al-Fikr, 1994. , al-Tafsir al-Wajiz 'ala Hamisy Alquran al-'Azhim. Damaskus: Dar , al-Tafsir al-Wasith. Damaskus: Dar al-Fikr, 2006.

2013.

Zulfikar, Eko. "Peran Perempuan Dalam Rumah Tangga Perspektif Islam: Kajian Tematik Dalam Alquran Dan Hadis". DIYA AL-AFKAR: Jurnal Studi al-Quran dan al-Hadis 7, No. 1 (2019). 
156 | AL QUDS : Jurnal Studi Alquran dan Hadis vol. 3, no 2, 2019

Halaman ini dikosongkan 